\title{
Spenser and the English literary system in the 1590 s
}

The previous two chapters have analyzed Spenser's methods of creating satirical meaning in his early poetry. It would now be sensible, and might even be expected, to devote a chapter to the satirical episodes in The Faerie Queene, especially the second installation of 1596, which includes a great deal more allegorical commentary on contemporary historical events than the first three books do. Instead, I veer in another direction entirely and in the remainder of the book will consider how other poets used Spenser as source material and used ideas about Spenserianism, shared with their audience, to help them signal their own satirical and topical meanings. Specifically, I will aim to discover what Spenser's contemporaries thought about him as a satirist by looking at how they adapted and alluded to poems from The Shepheardes Calender and from the Complaints volume. This focus on reception and influence precludes close attention to the satirical elements in The Faerie Queene, because Spenser's epic did not influence satirical poetry of the time period as clearly and significantly as did others of his works. To put it mildly, it would have appeared presumptuous in the extreme for a young satirist of the 1590s to use The Faerie Queene as a pretext. Although I argue in this chapter that Joseph Hall does precisely that in Virgidemiarum Sixe Bookes, it was a bold move, which he presents as such and mitigates through obsequiously emphasizing the value of Spenser among poets. In my study, I have found Spenser's earlier, shorter, more modest (in rota terms) poetry to be more productive of imitation and allusion among younger poets in the 1590s and early 1600s, and so I leave aside an in-depth analysis of satire in The Faerie Queene to focus, as my subtitle indicates, on a tradition.

My overall goal is to create a fuller and more nuanced view of Spenser's influence on satirical poetry in England in the 1590s and the impact of Spenser's role in the literary system on poets writing satire. Even though Spenser has never been thought of as primarily a satirist, his over- 
whelming importance to poetry in general by the last decade of his life means that he served as both an authorizer of and influence for poets who sought to fashion themselves as satirists. I believe that Spenser, as "Prince of Poets in His Time," by the 1590s exerted a disproportionate influence on literature, specifically satirical poetry, written during and after his life. His clearly defined authorial "brand" made "Spenser" a source of stable cultural meanings that poets could allude to or react against in order to clarify their own satirical messages while forestalling criticism, censorship, and punishment. In this chapter, after initial attention to the theoretical groundwork for thinking about the roles that Spenser played in his fellow writers' imaginings of the English literary system near the turn of the seventeenth century, I will focus on two friends' somewhat reductive treatments of Spenser in their own works. William Bedell's simplistic and repetitive Spenserianism clarifies what tropes and images predictably called the concept "Spenser" to the minds of writers and readers in the late sixteenth and early seventeenth centuries, while Joseph Hall's disgusting parodies of Spenserian images and language from The Faerie Queene, which serve to contrast his own aggressive indecorousness with Spenser's famous decorum, suggest the satirist's impatience with the epic poet.

\section{Theories of literary interconnectedness}

Itamar Even-Zohar's ideas on literary "interference" (i.e., influence), his conception of literature as a "polysystem" of numerous connected systems, and his ideas of center/periphery and canonical/noncanonical provide less historically and ideologically weighted perspectives on the complexity and connectedness of literary systems than those of Pierre Bourdieu. However, his ideas are not as well known within English studies as they are in the fields of comparative literature, especially translation studies, and so I will spend some time highlighting a few concepts that inform the chapters that follow.

Although Even-Zohar argues, somewhat tendentiously I think, against borrowing individual ideas piecemeal from his comprehensive theory ("Introduction," 4-5), one cannot avoid the reality that certain elements of his theory have more or less descriptive or explanatory power for particular situations, and thus I focus my attention on those points that provide the most help in conceptualizing the lines of influence connecting Edmund Spenser to other English satirists. Even-Zohar defines literary "interference" in a way that indicates its similarities to what is more typi- 
cally called "influence": "a relation(ship) between literatures, whereby a certain literature A (a source literature) may become a source of direct or indirect loans for another literature B (a target literature)" ("Laws," 54). Not surprisingly, given the terminology of the definition, to date these ideas about literary interference have been explored primarily with reference to inter-cultural transfer and influence, such as conceptualizing, for example, the impact that a hegemonic culture can have on the cultural productions of a less powerful culture, as in comparatists' recent discussions of the disproportionate influence of the English-language literary system on the literary systems of other nations and peoples (e.g., Moretti, "Conjectures"; and Moretti, "More conjectures"). The word "interference" perhaps goes too far in providing a negative judgment of the phenomenon, and this stems, no doubt, from a desire to root for underdog literary systems in their battle for self-determination; Franco Moretti highlights this sense of the word when he glosses Even-Zohar's terms as "powerful literatures making life hard for the others-making structure hard" (Moretti, "Conjectures," 65). Despite this justifiable emphasis on intercultural exchange and transfer, I argue for the relevance of Even-Zohar's "laws of literary interference" at the intra-cultural level, because even within a single nation or group, the polysystemic nature hypothesized of the literary system means that there are more and less privileged and powerful genres, publishers, authors, critics, and so forth in relationships within a single polysystem. How, we might ask, does the hegemony of the novel at the present day interfere with poetry, or with short stories? What does the towering stature of Shakespeare within early modern English studies mean for graduate students considering dissertation topics? Interference, understood as the impact of one disproportionately powerful node in the literary polysystem on other nodes in relationship with it, happens frequently intra-culturally as well as inter-culturally, and so I see Even-Zohar's "laws" as important in thinking of the ways that Edmund Spenser, and especially his indirect form of satire, "interfered" with and influenced the work of other near-contemporary English poets writing satire. In the time period I focus on here, state censorship also comes into play, limiting the choices available to individual authors while also affecting authors' overall sense of what is permissible, safe, or effective in the literary subsystem of satire.

Spenser's importance to the literary system of satire in England in the 1590s derives, I believe, from two sources: Spenser's extremely high poetic status, earned by his work in high-prestige genres such as pastoral and epic, and his reputation as a courageous poet who has no fear of 
criticizing the powerful, earned primarily by his work's being censored in 1591. To start with Spenser's disproportionate status in his literary polysystem, consider the following "laws" in thinking about Spenser as a possible influence on other writers: "2.2. A source literature is selected by prestige. 2.3. A source literature is selected by dominance" (EvenZohar, "Laws," 59). With the 1590 publication of the first three books of The Faerie Queene, followed in 1591 by his reward from Queen Elizabeth of a $£ 50$ annuity for life, Spenser's status as the premier English poet of his time was assured, but his poetic reputation was already quite strong before those events. We can gain a sense of his importance from the numerous references to him and his works in contemporary writings, as documented by R.M. Cummings (Spenser); Ray Heffner, Dorothy Mason, and Frederick Padelford (Spenser Allusions); and more recently by Jackson Boswell (Spenser Allusions). In 1586, for example, William Webbe assigned Spenser "the tytle of the rightest English Poet, that euer I read"; for Thomas Nashe in 1589 he was "diuine Master Spencer, the miracle of wit"; and so forth (Heffner et al., Spenser Allusions, 7, 13). ${ }^{1}$ Spenser's dominance is also suggested by his importance-in his own time and through the eighteenth century - as a model for young men in particular, leading Richard Frushell to term him "the young poet's poet" (Frushell, Edmund Spenser, 12). To sum up, by the 1590s, Spenser had both "prestige" and "dominance" in the English literary system.

Additionally, with the publication of the epic Faerie Queene, Spenser did much to advance English literature as an independent national literary system and to fashion himself as a laureate poet, as Richard Helgerson has demonstrated (Forms of Nationhood; Self-Crowned Laureates). Significantly, though, part of his reputation in the 1590s derived from the fact that the Complaints had been censored, contributing to the sense of Spenser as a courageous writer who valued truth over flattery. For young poets writing in English, and especially for those working in the less prestigious genre of satire, Spenser had a lot to offer as a model and, in some sense, authorizer of the project of writing English poetry and/ or satire. In this regard, Even-Zohar's idea of literature as a polysystem is helpful, because it reminds us to consider the multiple types of nodes in the system (e.g., genres, publishers and publication formats, authors) and the hierarchies that exist within and among these nodes as systems in their own right, with their own sets of relations. Even-Zohar defines the literary system as "The network of relations that is hypothesized to obtain

1 See Radcliffe, Edmund Spenser, 9-11, for more discussion of Spenser's literary reputation with his contemporaries. 
between a number of activities called 'literary', and consequently these activities themselves observed via that network," thus emphasizing the dynamicity and relationality of the system ("Literary system," 28). We can think about the hierarchies that obtain within these relations-specifically vis-à-vis satire as a stepchild genre in Spenser's England-by means of Philippe Codde's clarification of Even-Zohar's hypothesized continua central/peripheral (textual models that influence the creation of new texts are central; those that do not are peripheral) and canonized/noncanonized (texts and textual models with cultural prestige are canonized; those without are noncanonized). Codde separates these two continua to create a more comprehensible set of (four) possibilities:

(1) canonical + central: this would be the logical situation, where items or models that enjoy prestige in the system influence the production of other cultural items or models in the system ...; (2) canonical + peripheral: here belongs the case of the Shakespearean sonnet [at the present day] and other models and items that are prestigious, though no longer influential; (3) noncanonical + central: this would be the case of models and artifacts that are popular and therefore occasion much imitation, even though they are far from prestigious (i.e., they enjoy no critical acclaim and are not taught in schools or colleges); (4) noncanonical + peripheral: this is the position of works and models that are generally considered inferior, both by other artists (who do not use them as models) and by critics and institutions (who do not grant them prestige). (Codde, "Polysystem theory," 104n18)

I can use this taxonomy to clarify a central claim of this book: Spenser by the 1590s was already canonized as an author, with Shepheardes Calender and Faerie Queene also to be viewed as canonized texts, and these works were also central in terms of inspiring other English poets to create pastoral and epic poetry modeled on Spenser's. But although satire as a genre lacked prestige in early modern England, "diuine Master Spencer" also published a number of satirical poems in the innocuous and medieval-sounding Complaints volume, ${ }^{2}$ and these, not famous but

2 The classic analysis of complaint versus satire is John Peter's Complaint and Satire in Early English Literature (1956). Peter sees Spenser as important to the history of neither complaint nor satire: "Spenser again, whatever his interest in another context, is hardly a key-figure in the development of Satire. His allegorical method is distinctly medieval ... but its affinities are with political songs rather than complaints proper... . Beyond Drayton's The Owle, moreover, which will be mentioned later, [Mother Hubberds Tale] seems to have had very little contemporary influence" (132-33). Obviously, I disagree with this conclusion. The polarizing nature of satirical writing means that critics' own preferences can cloud their genre analyses; Peter, for example, likes complaint and dislikes formal verse satire, and this preference influences all of his judgments. On the other hand, to Kirk Combe, complaint sounds "frequently whiny and distressingly acquiescent," and, 
notorious, served to connect the illustrious laureate poet Spenser with the genre of satire. These satirical works were never canonized texts, in part because the collection was called in by the authorities shortly after publication and in part because the poems in the collection worked within less prestigious genres than epic and pastoral.

But although these works were not canonical in late Elizabethan England, they were, still following Codde's taxonomy, central, not peripheral. That is, although other writers carefully avoided obvious imitation of Spenser's satirical poems (and Thomas Nashe's disgusted response to Gabriel Harvey's reference to the scandal just under two years later suggests a general preference not to mention the matter at all, to avoid "rekindl[ing] against him the sparkes of displeasure that were quenched" [Nashe, Strange Newes, 281]), other poets' use of his indirect satirical methods and their allusions - real but not obvious-to some of his satirical poetry clarify the ways in which his work in satire was central to poets working within the mode in the 1590s. So, when young satirists alluded to Spenser, modeled their works on his, or otherwise rode on his coattails, they did so as practitioners of an uncanonized and largely peripheral genre looking to the canonized author Spenser to add meaning to their works and some authority to their genre. Given that Spenser spent most of the 1590s living in Ireland, we must think of the influential force as textual and conceptual: that is, Spenser-as-author, the name "Spenser" serving as a means of classifying texts, discourses, and ideas, as Michel Foucault imagines "the author-function" (Foucault, "What is an author?"). Foucault reaches backward in time to borrow Jerome's criteria for what constitutes an "author"; I will embrace anachronism to connect Foucault's ideas about the author-function as depending in part on the quality and consistency of texts to the contemporary marketing concept of the "brand."

Linking ideas about branding to work in architecture and design, Peggy Deamer distinguishes between "fame," which is inaccessible and which requires a clear identification between author and product, and the "brand," which, on the other hand, depends on repeatability and accessibility (Deamer, "Branding," 42). To the extent that no one but Spenser could write works as enduring and valued as his own, Spenser had fame, but I speak of "branding" as a way of thinking about the numerous poets who tried to write like Spenser as well as the authors who connected their own works to their audience's idea of Spenser through allusion rather than imitation, including the handful I discuss in this book. Without a

so to his eyes, the seventeenth-century shift from complaint to satire was a good thing ("New voice," 75). 
literary model that seems reproducible and accessible, no one would try to write a Spenserian poem. For this reason, the poetry of Spenser has spawned more imitators than, say, the plays of Shakespeare, presumably because poets see in Spenser's works, and in their ideas about "Spenser," elements that seem accessible for imitation or adoption as part of their own authorial personae. To return to Even-Zohar's laws of literary interference, he asserts that "Appropriation tends to be simplified, regularized, schematized" ("Laws," 59). As we will see, a coherent picture of "Spenser" develops from examining other writers' uses of him: politically, he is censored, unappreciated, and exiled (i.e., "oppositional"); culturally, he is high class; as a satirist, he is indirect, using allusion and allegory, especially pastoral and animal allegory, to create deniability for his attacks.

The way that other writers made use of this general understanding of the meaning of "Spenser" changed over time, however, as the political situation in England changed. After the censoring of the Complaints volume, poets did not closely imitate Spenser's satirical works during the remainder of Elizabeth's reign. Instead, poets signaled the importance of interpretive reading and aligned themselves with the values and political positions considered "Spenserian" through allusion, sometimes quite veiled allusions. Only later, in the early seventeenth century, following both the 1599 Bishops' Ban targeting formal verse satire (among other genres) and the 1603 death of Elizabeth, did satirists begin to connect themselves with Spenser by openly imitating those features of his writing that were most repeatable and accessible, the characteristic linguistic and generic moves recognizable to contemporaries as "Spenserian."3 Only then do we find the directly imitative pastoral satires of the "Spenserian poets" or the allegorical beast fables examined by Hoyt Hudson ("John Hepwith's"). Although both of these ways of "using" Spenser in early modern English satires interest me, the bulk of this study will focus on the allusive practices of the 1590s.

\section{Spenserianism simplified: two reductive responses to Spenser}

In the chapters that follow, I will discuss some very artful and sophisticated uses of and responses to Spenser in satirical poems written by his near-contemporaries, but, first, I want to spend some time on two writers, friends and future illustrious bishops, whose uses of Spenser in their works provide a sense of the caricature version of what "Spenser"

3 Of course the very most Spenserian thing about Spenser is the "Spenserian stanza" of The Faerie Queene, which was imitated over and over again across the centuries. Because this stanzaic form is of only tangential interest for the topic of satire, I pass over it in the text. 
meant to his contemporaries in the late sixteenth and early seventeenth centuries. In the remainder of this chapter, I will explore how "Spenser" appears in poetry by William Bedell (pronounced like "beadle") and Joseph Hall. These remarkable men became friends while studying at Emmanuel College, Cambridge (Bedell admitted 1584, elected fellow 1593; Hall admitted 1589, elected fellow 1595), a college founded in 1584 by Sir Walter Mildmay to train staunchly Protestant young men for the ministry (for details of Mildmay's religious goals for the new college, see Bendall et al., A History, 17-25). Given the college's Puritan leanings, it is not surprising that Bedell and Hall were the only two bishops produced by Emmanuel before the Civil War, which suggests something of their religious moderation during those politically and religiously difficult times (Bendall et al., A History, 82, 84, 88). Between 1601 and 1607 , both served in parishes in Suffolk-Bedell at Bury St. Edmonds and Hall at Hawstead-and continued their friendship (Bendall et al., A History, 84, 88). Hall wrote a commendatory verse for Bedell's poem on the Gunpowder Plot; both contributed verses to the 1606 obituary volume for Edward Lewkenor and his wife Susan (Threnodia, 27-28 for Bedell, 30 for Hall); and both took part in an epistolary exchange with James Wadsworth, a friend and former fellow minister whom they had known at Emmanuel and in Suffolk who had moved to Spain, converted to Catholicism, and become a pensioner of the Inquisition.

In the exchange with Wadsworth, which Bedell published after Wadsworth's death, we can see the contrasting personality traits of Bedell and Hall that appear as well in the poems I will discuss, with Bedell gentle and kind-hearted and Hall irascible and sarcastic. ${ }^{4}$ Bedell seeks common ground with Wadsworth, with assertions such as "Incomparably more and of more importance are those things wherein wee agree; then those wherin we dissent. Let vs follow therefore the things of peace, and of mutuall edification"; he also offers reminders of their long friendship, as in "I hope you shall perceiue that setting aside our difference in opinion, I am the same to you that I was when we were either Schollers together in Emmanuell Colledge, or Ministers in Suffolke" (Wadsworth and Bedell, Copies, 160-61, 36). Wadsworth adopts a similarly conciliatory tone, leading Izaak Walton to comment that in the letter exchange, "there seems to be a controversy, not of Religion only, but who should answer each other with most love and meekness; which I mention the rather, because it too seldom falls out to be so in a book-war" (Walton's

4 For more on Wadsworth's life, see Marotti, Religious Ideology, 119-21, 123; and Questier, Conversion, 80-81. 
Lives, 153). Hall, on the other hand, shows in his one letter included in the collection the tendency toward bitter taunts familiar to readers of his Virgidemiarum, written almost twenty years earlier. Although we do not have Hall's original letter to Wadsworth, Wadsworth characterizes it as "satyrical" and expresses particular hurt that Hall accused him of apostasy (Wadsworth and Bedell, Copies, 16, 2). The letter from Hall to Bedell included in the collection suggests the railing and harsh tone he may have taken in his lost letter to Wadsworth: "what a sorry crabb hath Master Waddesworth at last sent vs from Siuill? I pittie the impotent malice of the man; sure that hot Region, and sulphurous Religion are guiltie of this his choler. For ought I see hee is not onely turned Papist but Spaniard too" (Wadsworth and Bedell, Copies, 30-31). Though a moderate politically and religiously, his approach to controversy was anything but gentle, and his later published dispute with Smectymnuus (answered by John Milton) indicates that his truculence would last his whole life. Looking at Spenser from the perspectives of Bedell and Hall can give us a sense of what his contemporaries thought he "meant," in terms of both poetry and morality.

\section{William Bedell's Shepherd's Tale of the Pouder-Plott:} reproducing the Spenser brand in a topical poem

William Bedell, future bishop of Kilmore in Ireland, was inspired by the successful foiling of the Gunpowder Plot to write a poem about it (published in 1713 as A Protestant Memorial; or, The Shepherd's Tale of the Pouder-Plott); he took such pride in the poem that, according to his son-in-law and biographer, Alexander Clogie, he read it aloud to his household each year on November 5 (Clogie, Speculum, 194). ${ }^{5}$ Arnold

5 Karl Reuning argues against Bedell's authorship of the poem, but his evidence is weak and does not take account of Clogie's testimony. He offers a useful and very detailed discussion of the textual history of the poem, but his arguments against Bedell's authorship do not convince. Reuning tries to prove that the poem is an early eighteenthcentury fake by analyzing handwriting and biographical details, but the argument ignores key evidence. Reuning uses the fact that Bedell's biographer Gilbert Burnet does not mention Bedell's poetry as evidence that the poem did not exist in 1685. Reuning cites the Shuckburgh edition that includes Alexander Clogie's biography but does not mention Clogie's reference to the poem (Reuning, "Shepherd's Tale"). Burnet himself acknowledges his overwhelming debt to Clogie, son-in-law and close associate of Bedell in the last years of his life (calling him "much more the Author of this book than I am"; Burnet, Life, 175), and thus we must view Clogie's reference to Bedell's annual reading of his poem as more authoritative than Burnet's failure to mention the poem one way or the other. Julius Hook summarizes Reuning's arguments uncritically (EighteenthCentury Imitations, 75). Frushell follows Reuning, adding his opinion that the poem was composed as a satire in response to the political situation in 1713. Surely, the 1712 "Bandbox-Plot," an attempt on the life of Robert Harley, Earl of Oxford, that was foiled 
Davenport creates a convincing timeline for the composition of this poem - to account for the dedicatory poem by Bedell's friend Joseph Hall, Davenport hypothesizes that Bedell wrote the poem and shared it with his friend at some point between the discovery of the plot in 1605 and Bedell's departure for Venice with Sir Henry Wotton in 1607, because, during that time, Bedell and Hall lived only four miles from each other (Davenport, "Commentary," 269-70n15).

The 1713 published version of the poem opens with Joseph Hall's poem to his friend, in which he sets the Spenserian stage by opining that "Collin dying, his Immortal Muse / Into thy Learned Breast did late infuse" (C1r; a footnote identifies Collin as "Spenser" for the eighteenthcentury audience). In Bedell's poem, we find a précis of what contemporaries considered the hallmarks of Spenser's poetry. To call Bedell a "poet" would overstate his talents, but his status as "imitator" can tell us much of interest, because his unskillful imitation highlights what seemed, following Peggy Deamer's formulation of the brand, reproducible and accessible in the work of the master. These details-shepherds, sheep, and foxes-can provide us with insight into what "Spenser" meant to his contemporaries.

Bedell's poem begins with a typical pastoral dialogue between Willy and Thenot (later, a character named Perkin will appear with no introduction): Willy wants to "Pipe and Play" to celebrate the lucky escape from "the darkest Day / That ever lowerd on the British Shore," but Thenot has not heard the happy news of the foiling of the thinly allegorized story of the Gunpowder Plot (Bedell, Shepherd's Tale, 1-2). After a few speeches back and forth, the dialogue turns into Willy's 443-line interpolated tale of the Catholic plot to blow up "the Senate of Shepherds" (13). The low quality of the poetry will become apparent from the quotations I include, and this need not trouble us here. In general, as an imitator, Bedell focuses on key Spenserian characteristics such as archaic language and alliteration, and easily copied pastoral poetic forms such as the roundelay form seen in, for example, "August" of The Shepheardes Calender. In terms of Spenser's satirical methods, Bedell apes Spenser's well-known use of pastoral and animal allegories, but, because Bedell's poem is politically safe, he does not need to make his allegories actually difficult to decipher: one part panegyric of the victorious king plus one part satire

by the quick wits of none other than Jonathan Swift, resembles in important ways the story of the Gunpowder Plot (Harley received a package containing pistols that were to be triggered by the box's opening), but these similarities can explain the 1713 publication of Bedell's poem without requiring us to deny his authorship of the poem. 
of the perpetrators (who have already been drawn and quartered) and the Catholic Church (which requires no particular courage to criticize in seventeenth-century England) equals an utterly transparent allegory.

Bedell shows his awareness of the fictional space and time of pastoral that appear regularly in pastoral, but this awareness flags as he warms to the topic of the Plot. Spenser, following his own models in earlier pastorals, pays attention to verisimilitude in creating the pastoral world in which his shepherds exist, so that, for example, the sun sets, leading shepherds to finish their talk and lead the sheep to the fold, thus closing an eclogue. In the eclogue most concerned with the city, "September," Spenser maintains the pastoral setting through frequent changes of speaker-Diggon Davy's lament never becomes a monologue-and extremely frequent references to sheep. During the lengthy narration about the Plot, Bedell seems to recognize that he has lost track of the pastoral setting and frame story and attempts to correct the oversight by having Willy interject one comment that reminds readers of the setting and the supposed audience for Willy's monologue- "But let me see; whereof said I this? / Ah! well bethought" (Bedell, Shepherd's Tale, 19)—before wrapping up his narration. Too little, too late, though: during Willy's monologue, readers lose track of the pastoral frame setting, and the scene and story both feel firmly bound to the city, despite Willy's references to the King, Queen, and members of Parliament as "shepherds."

Still, Bedell creates a reasonably effective allegory in the extended metaphor of the "sickness" of Catholic "sheep" reminiscent of the allegorically ailing sheep belonging to such Spenserian shepherds as Colin Clout and Diggon Davy. Perkin describes the view he used to hold of the Catholic sheep:

I had yweend; and so had many more,

They had been simple, souple, meek, and poor;

And eek as other Sheep, methought, they bleat,

Albe for sick they did forsake their Meat.

At most I would have thought they scabbed were,

Or fly-stung so they gadded here and there.

Their ragged Pelts I pityed all to rent,

Whilst in the bushy Thickets they miswent.

(Bedell, Shepherd's Tale, 25)

Perkin has realized the error of this view and now understands that these sheep have "monsters" within their breasts and cannot be cured. Willy concurs, advising that shepherds should chase or kill the monstrous sheep and work to preserve the health of the good flocks: 
To make strong Fence, and sure, that may hold These Leapers, and keep them in Pasture and Fold. For souverain'st Medicine is sweet and clean Feed On virtuous Hearb, without rank and fowle Weed. Such can preserve the Flocks in good Plight, And heal their Diseases, and well acquite The tender Lambs from ill Eys, as I guesse, And all the Charms of the false Sorceresse.

The false sorceress, naturally, is the Roman Catholic Church, about whom more later.

The pastoral frame story thus contains certain familiar conventions, such as the insistent sheep metaphors and imagery at the beginning and after the end of Willy's monologue, as well as the movement from country to city and back again with news, as occurs in "September" of The Shepheardes Calender and in Colin Clouts Come Home Againe. Willy can tell Thenot about the events of the Plot and its foiling because he was in the city five days earlier and saw for himself "the Bonfires, the Mirth, and the Jollity; / The Ringing and Singing, and all the Glee" (20). Additionally, the poem that Willy recites at the end, a roundelay with one voice speaking the lines of Psalm 124 and the undersong connecting the psalm to the Gunpowder Plot, clearly derives from Spenser's "August" not just in the form but in the language used to describe it: "his Fellow Swain, / The under-Song him answerd again" (27). Spenser coined the term "undersong" in "August" of The Shepheardes Calender (line 128), and the Oxford English Dictionary records no other use of the word before Spenserian poets Michael Drayton in 1606 and William Browne in 1616 (although the editors ignored Spenser's own repetitions of the word in Daphnaïda [line 245] and Prothalamion [line 110]), so the word itself suggested Spenser when Bedell wrote the poem between 1605 and 1607 (s.v. "undersong"; see also Hollander, Melodious Guile, chapter 8, titled "Spenser's Undersong").

We find another word likely to remind readers of Spenser in Willy's reference to "Lobbin," the source of his details about the Plot: "Of many good Shepherds I heard the same, / And from the sage Lobbins own Mouth it came; / The wise Lobbin, that Fame doth resound, / As true a Shepherd as lives on the Ground" (Bedell, Shepherd's Tale, 21). Bedell here provides readers with an allusion considerably harder to decipher than, say, the reference to the Monteagle letter ("So said this Letter. I heard his Name neven, / Mount it began with to whom it was given" 
[17]). ${ }^{6}$ The presumed counterpart of Spenser's Lobbin in "November," Robert Dudley, Earl of Leicester, was of course long dead by the time Bedell wrote. His son and heir, Robert Dudley (1574-1649), left England forever in July 1605, and thus he cannot be Lobbin (Adams, "Dudley"). Edmond Malone cites Bedell's use of the name Lobbin to support his contention that the identity of the Earl of Leicester was generally known, arguing that Bedell uses the name Lobbin to connect his Lobbin (whom Malone believes to be Robert Cecil) with Spenser's Lobbin by means of their shared given name (Malone, "Life," 202n5). Cecil seems an adequate identification, though it jars somewhat to think of a Spenserian shepherd praising a Cecil.

The Shepherd's Tale of the Pouder-Plott clearly owes more to The Shepheardes Calender than to Spenser's Mother Hubberds Tale as a model, yet Bedell's heavy-handed use of animal imagery and allegory at times suggests conscious allusion to Spenser's beast allegory. Of course we find animals in pastoral as well, and, predictably, the animal imagery in the pastoral frame story feels less like "beast fable" and more like shepherding concerns, but with some foreshadowing of the obsessive use of animal allegory in the interpolated tale of the Plot. For example, Thenot's question about Willy's reason for celebrating serves to introduce the phrase "false Fox," which Willy will later use twice to refer to Guy Fawkes: "What might the Danger be, that was so dern? / ... . / Or hath some wicked Woolf, or Beast more stern, / (As Beare, or Boare) been spied in Halk or Hern? / But if false Foxes be, that would us shend, / We have true Currs that shall them well defend" (2).

Willy twice refers to the allegorical version of Guy Fawkes as the "false Fox" (14, 19): "False was his Name, I remember well, / As well it fitt him, they say that can tell. / A false Fox it was in Mans-shape ydrest, / Enclosing a false Fiend in his Breast" (14). Richard Hardin notes that poetry of the Gunpowder Plot often punned on the names of the perpetrators, but the puns Hardin cites for Fawkes connect him with fallax or falseness, not with foxes ("Early poetry," 65). Bedell thus connects his poem to other Gunpowder Plot poetry with the standard pun "false," but he connects himself as well to Spenser through the phrase "false fox," which occurs four times in Mother Hubberds Tale and twice in the "Maye" eclogue of The Shepheardes Calender. Although, as Thenot's reference to the danger from "false foxes" acknowledges, foxes are part of the pastoral world, with Willy's description of this human fox we can perceive a shift

6 For more details on the letter, see Nicholls, Investigating, 6-8, 174-75. 
in how Bedell uses animals to convey his ideas: Thenot fears real foxes, but Willy speaks of beastly humans, and thus we enter the realm of the beast fable in the interpolated tale of the plot. Within the allegory of the interpolated tale, the sorceress who represents the Catholic Church turns men to beasts with her enchanted cup:

What Mouth of that Cup once kisse the Brimm,

Albe he seemeth a Man, as before;

Inly a Beast he is and no more:

A fierce Lion, a Woolf ravenous,

Or cruel Tiger, or Fox cautelous,

Or grizly Beare, or Dragon hideous,

Or other like Monster outrageous.

(Bedell, Shepherd's Tale, 6)

This sorceress is far more "cunning" than Circe, who could "transform Men to Doggs, / Woolves, Foxes, Beares, Lions, Tigers, Hoggs / . . . / Soon as they drunk of her charmed Wine, / Right anone were they changed into Swine" (5). But Circe could change only the body, not the mind, whereas this (Catholic) sorceress leaves men's bodies unchanged on the outside, but transforms them within to beasts. However irenic Bedell may have been in his correspondence with James Wadsworth, his real antagonism to the Roman Catholic Church (if not to individual believers) appears in this allegory and fits with his other published writings. ${ }^{7}$

This tale of origin renders it unnecessary to explain the motives of the plotters: the Catholics- "these misformd Monsters," "that beastly shaped Crue" (12)-are no longer human and thus act on behalf of the sorceress. Later, after the conclusion of the interpolated tale, when the pastoral dialogue resumes, the discussion of what to do about the sick sheep, quoted above, hearkens back to this tale of origin about what makes Catholics different and why efforts to "cure" (that is, convert) them are a waste of time: "Within their Breasts such Monsters doe they keep," and so the best course of action is "to chasen these Monsters away, / Or doe them dead without more Delay" $(25,26)$.

Bedell knows how to imitate the most recognizable features of Spenserian satire: allegories of shepherds and animals create a clear comment on a recent important event, the Gunpowder Plot. Surely, though, Bedell

7 See Milton, Catholic and Reformed, 40-42, 112, 161-62. Despite his anti-Catholicism, Bedell showed pastoral concern for the Irish Catholics when he was Bishop of Kilmore. Although laws promoted the English language and English customs, Bedell preferred to appoint Irish-speaking over monolingual ministers, because, he said, "those people had souls which ought not to be neglected till they would learn English" (qtd. in Jones, A True Relation, 44). 
misses the spirit of Spenserian satire, which uses indirection and ambiguity to manage the risk of criticizing or even mocking people with real political power. Bedell takes no risks with this poem, because the satire targets a reviled out-group, English Catholics and the subset of English Catholic Gunpowder Plotters, and works to create a strong sense of group solidarity and self-congratulation among English Protestants, in line with Fredric Bogel's argument that satire functions socially to demarcate and police the boundary between social insiders and outsiders (Bogel, Difference Satire Makes). The first two stanzas of the closing roundelay, alternating lines from Psalm 124 and summary of the Gunpowder Plot, exemplify the effort to connect the English Protestants with the people of Israel and to strengthen the sense of group cohesion: ${ }^{8}$

S. When Men against us did arise,

F. Cruel Beasts in Shapes of Men,

S. And to destroy us did devise.

F. We had bin devoured cleane,

S. Had not the Lord bin on our side;

F. Now may Britain justly say,

S. Had not the Lord bin on our side,

F. In that dark and dismal Day.

Whereas the circuitousness of Spenser's satires provides intellectual pleasure in the form of puzzles to solve, Bedell aims to provide the emotional pleasure of vindication and victory for his side and complete dehumanization of the enemy camp. Still, this somewhat tin-eared imitation provides a summary of what, in its simplest form, "Spenserian satire" meant to one of Spenser's near-contemporaries who admired his work enough to want to imitate it.

\section{Joseph Hall and the anxiety of Spenser's satiric influence}

Bedell's friend Joseph Hall, on the other hand, although he repeatedly mentions his admiration for Spenser, approaches Spenser much more critically in his own work than does Bedell, presumably because of his generally more choleric temperament. In 1597, Joseph Hall published the first installment of Virgidemiarum Sixe Bookes. First Three Bookes, Of Tooth-lesse Satyrs 1. Poeticall. 2. Morall. 3. Academicall; the second half, the Byting Satyres, followed in 1598. With this work Hall initiated

8 See Guibbory, Christian Identity, for discussion of the development of this imagined connection across the century. 
the fashion of modeling English satires on the satires of the Roman author Juvenal. The fad was short-lived, however, because in 1599 the Bishops' Ban, after listing a number of satires to be called in and burned, including Hall's at the top of the list, would decree "That noe Satyres or Epigramms be printed hereafter" (qtd. in McCabe, "Elizabethan satire," 188). ${ }^{9}$ Whereas scholars have considered how the Bishops' Ban led poets to alter their approaches to satirical writing, the impact of Spenser's 1591 censorship episode on satirical poetry in England has been less carefully studied. Even though Spenser's personal danger had blown over within a year or two, the censorship cast a sufficient pall on literature that no beast fables were written in England for the rest of the decade, and I know of no literary allusions to Mother Hubberds Tale made during the 1590s, despite the popularity of the poem in manuscript during the two decades that the poem was out of print (Beal, Index, Vol. 1, part 2, 527-28). For an author writing satire in the middle of the decade, it might have seemed safer to avoid acknowledging even the existence of previous satires in English, and Hall takes that course. In the Prologue, he boasts:

I First aduenture, with fool-hardie might

To tread the steps of perilous despight:

I first aduenture: follow me who list,

And be the second English Satyrist.

(Hall, Virgidemiae, I.Prologue.1-4)

This puffed-up tone must betray some anxiety, and Hall's insistent allusions to Spenser in "His Defiance to Envie," which opens the collection, and in several of the satires of the first three books, suggest that Spenser may stand as the most important source of this authorial anxiety. Significantly, however, Hall alludes in his satires to The Faerie Queene, not to any of the poems in the Complaints volume, despite the fact that he surely knew of the book, not only because the author of Book 1 of Virgidemiae, focusing on abuses in poetry, had a strong grip on the English literary scene in the 1590s, but also because he specifically references The Ruines of Time in 1605, in a sidenote of his satirical utopian work Mundus Alter et Idem (translated in 1613 by John Healey as The Discovery of a New World; see Heffner et al., Spenser Allusions, 99; Boswell, Spenser Allusions, 374).

So although Hall presumably knew of the critical and politically charged poems of the Complaints volume, instead of engaging with that side of Spenser in his works as the supposed first English satirist, he

9 Note that Virgidemiae, along with Thomas Cutwode's [Tailboys Dymoke's] Caltha Poetarum, was "staid" and not burned along with the others (McCabe, "Elizabethan Satire," 190). 
instead tilts at a purposefully simplified Spenser, the Spenser of decorum and politesse. Hall probably differentiates his work both stylistically and generically from the satirical poetry of Spenser at least in part to avoid the same fate for his work-ultimately unsuccessful, of course-but I believe also that Hall's self-consciously anti-Spenserian passages offer a muted critique of Spenser's own authorial persona as insufficiently harsh, too conciliatory, a criticism that could easily be transferred to Spenser's characteristic indirection in satire as well.

The question of Hall's attitude toward Spenser vexed a number of twentieth-century critics, and with good reason. All of Hall's direct references to Spenser praise him-for example, "At Colins feete I throw my yeelding reed" (Hall, Virgidemiae, "Defiance," line 107) and "But let no rebel Satyre dare traduce / Theternall Legends of thy Faery Muse, / Renowmed Spencer" (I.iv.21-23). However, some passages that appear to allude to Spenserian themes or images acquire a negative valence in the context of Hall's satire and thus convey a sense of ambivalence regarding Spenser. Critical responses to the issue often betray an unwillingness to engage with this doubleness, leading to such unambiguous assertions as "Spenser was Hall's literary idol"; Hall "declares Spenser off limits for the satirist"; and "all ... the indubitable references that Hall makes to Spenser are laudatory." ${ }^{10}$ Ronald J. Corthell addresses the ambivalence more directly than others; he finds "a weariness with Spenserian motifs" in Hall's declaration that he will not "scoure the rusted swords of Eluish knights, / Bathed in Pagan blood: or sheath them new / In misty morall Types: or tell their fights, / Who mighty Giants, or who Monsters slew" ("Defiance," lines 49-52) (Corthell, "Beginning," 51). Additionally, Corthell interprets Hall's comments on pastoral in "His Defiance to Enuie" as indicating that Hall chooses to begin his career with satire rather than pastoral because of a concern that "pastoral perspectives, while sharing some concerns

10 The quotations are, respectively, from Salyer, "Hall's Satires," 150; Jensen, "Hall and Marston," 81; and Davenport, "Introduction," xlii. Part of scholars' confusion regarding Hall's attitude toward Spenser stems from a probable misattribution of Certain Worthye Manuscript Poems of Great Antiquitie ... (1597) to Joseph Hall. Dedicated "To the worthiest poet Maister Ed. Spenser," the book is the only printed work dedicated to Spenser. Andrew Hadfield ("Spenser and John Stow") argues that the editor of the collection was in fact John Stow, but he understates the evidence for a connection to Hall: the poetry collection was registered along with the first three books of Virgidemiarum in the Stationers' Register on March 31,1597, and some volumes extant have the poetry collection bound together with Virgidemiarum; see Davenport (lxi), who explains the Stationers' Register error as a mistake caused by the clerk's misunderstanding of the "sixe bookes" part of the title, when only the first three books were in fact ready for press in 1597. 
with satire, must be skewed in order to contribute to a true image of the times" (Corthell, "Beginning," 51).

Corthell's comment on pastoral, satire, and the historical moment leads to the glaring omission in all accounts of Hall's ideas about Spenser: no one has previously considered Hall's response to Spenser as himself a satirist. I believe that Spenser's place within the satirical landscape of the 1590s explains both Hall's ambivalence and his anxiety to distance his work from that of Spenser. On the one hand, it is prudent for Hall to distinguish his work formally from the most famous recent case of censorship at the time; on the other hand, Hall implies that Spenser, with his decorum and allegory, did not go far enough to arouse the kinds of reader reactions that would lead to real reformation of vice. This explains as well the higher proportion of Spenserian allusions in the first installment than in the second of Virgidemiarum: these satires may be "toothlesse," he seems to say, but not as toothless as those of Spenser.

There is no critical consensus regarding either the reasons for the inclusion of Hall's satires in the list of books to be called in and burned or the reasons why Hall's book (along with Thomas Cutwode's [Tailboys Dymoke's] Caltha Poetarum), though still prohibited, was not burned. Scholars with specific theses regarding the motivation of the Bishops' Ban are not able to make Hall's work fit. For example, Clegg explains the ban as an attempt to protect the Earl of Essex from criticism, but she does not connect Hall's work to this thesis (Clegg, Press Censorship Elizabethan, 198-217). John Peter, with his emphasis on obscenity as the bishops' motivation, hypothesizes that Virgidemiae was reprieved from burning when the bishops realized that it wasn't as obscene as the other works on the list (Peter, Complaint and Satire, 149, 150). Hall's work can fit more easily with broader claims by authors such as Andrew McRae and Richard McCabe that view the bishops as responding to satire's ability to create political instability, with McCabe pointing specifically to Hall's anti-enclosure comments in satire iii of Book V (McRae, Literature, Satire, 5-6; McCabe, "Elizabethan Satire," 191).

Although Virgidemiae is not obscene, Hall delights in using disgusting imagery and harsh language to make his points. In this, he differs from the decorousness of Spenser, though the two men shared a moderate reformist Protestant political and religious perspective (see King, Spenser's Poetry; and McCabe, Joseph Hall). Hall emphasizes his intention to create a tone strikingly different from Spenser's by using offensive language and imagery in passages of the satires that clearly allude to Spenser. I will discuss three examples of this before turning to an analysis 
of what may have motivated Hall to add the element of disgust to these allusions.

Spenser frequently referred to the Muses in making criticisms of contemporary poetry, and Arnold Davenport argues that Hall's satire on the Muses alludes to both Spenser's translation of Jan van der Noot's $A$ Theatre for Worldlings (1569) and Spenser's Teares of the Muses, which was part of the Complaints volume (Davenport, "Commentary," 164-65). The idea of connecting a decline in poetry to mishaps that have befallen the Muses is certainly not original to Spenser-in his third satire, Juvenal speaks of the woods going begging because the Muses have been evicted ("eiectis mendicat silva Camenis," 3.16)-but Hall's readers would be more immediately familiar with Van der Noot's allegory of the Muses being swallowed up by the earth and Spenser's complaint by Euterpe that "a ragged rout / Of Faunes and Satyres, hath our dwellings raced / And our chast bowers, in which all vertue rained, / With brutishnesse and beastlie filth hath stained" (Spenser, Theatre, epigram 4; Spenser, Teares, lines 267-70; see Corthell, "Beginning," 55, for discussion of close verbal parallels between Spenser's Teares of the Muses and Hall's description of the Muses). However, whereas the home of Spenser's Muses is invaded against their will, in Hall's satire, the problems in poetry arise from the fact that the Muses have turned from "Vestall maides" (Hall, Virgidemiae, I.ii.1) into whores:

Some of the sisters in securer shades

Defloured were:

And euer since disdaining sacred shame,

Done ought that might their heauenly stock defame.

Now is Pernassus turned to the stewes.

The poem closes:

But since, I saw it painted on Fames wings,

The Muses to be woxen Wantonnings.

Each bush, each banke, and each base Apple-squire,

Can serue to sate their beastly lewd desire.

Ye bastard Poets see your Pedegree,

From common Trulls, and loathsome Brothelry.

(I.ii.33-38)

In both "His Defiance to Enuie" and the first satire of Book I, immediately preceding this poem, Hall had already declared that he was not competing with Spenser: "At Colins feete I throw my yeelding reed," he writes, and 
he will provide only "refuse rimes," not a "song" (Defiance.107, 113, 112). Furthermore, because the Muses have all left the Granta River (near Cambridge) to "haunt the tyded Thames and salt Medway / Ere since the fame of their late Bridall day" (alluding to the Thames-Medway marriage episode in Book 4 of The Faerie Queene), the best he can hope for near the Granta is a "baser Muse" (I.i.29-30, 27). Following these warnings, then, not to expect anything of the quality one might find in Spenser, Hall displays something else one would not find in Spenser: an image of whorish Muses selling their favors to sate their lusts.

The next poem, satire iii of Book I, continues the project of distinguishing Hall's work from Spenser by alluding to the story of Chrysogone from Book 3 of The Faerie Queene. Chrysogone, mother of the twins Amoret and Belphoebe, conceived them "Through influence of th'heuens fruitfull ray" when, as she slept, "The sunbeames bright vpon her body playd / ... / And pierst into her wombe" (FQ 3.6.6.2, 3.6.7.5, 7). The narrator explains that "reason teacheth that the fruitfull seades / Of all things liuing, through impression / Of the sunbeames in moyst complexion, / Doe life conceiue and quickned are by kynd" (FQ 3.6.8.36). Spenser here reiterates extremely common ideas about the origin of life that date to the classical period (see Lemmi, "Monster-spawning"; and Cumming, "Ovid"). Certainly the pervasiveness of references to the idea that, in the words of Himmet Umunc, "the origin of physical life was principally due to the generative effects of heat and moisture upon matter," suggests the importance of caution in identifying Spenserian allusions in references to the generation of life through sunbeams ("Chrysogone," 153). Nevertheless, Spenser's example of the sun's power of generation was surely the most fully developed and memorable example of this idea in the minds of Hall and his readers. In Hall's reworking of this idea of the sun's power in a satire on Christopher Marlowe, drunkenness, and literature, we see again the pattern of taking an image or idea that was beautified in Spenser and making it disgusting:

As frozen Dung-hils in a winters morne,

That voyd of vapours seemed all beforne,

Soone as the Sun, sends out his piercing beames,

Exhale out filthy smoke and stinking steames:

So doth the base, and the fore-barren braine,

Soone as the raging wine begins to raigne.

(Hall, Virgidemiae, I.iii.3-8)

We see direct verbal parallels here with the references to "piercing" and "sun ... beams" and a general similarity in the idea of the importance of 
interaction between sun and moisture in creating change.

I will discuss one more example of Hall's pattern of alluding to Spenser, but with a disgusting twist, a passage that begins with a verbal Spenser allusion in the characteristic "who knows not ...?" rhetorical question in another satire on drunkenness:
When Gullion did (who knowes not Gullion?)
And his dry soule ariu'd at Acheron,
He faire besought the Feryman of hell,
That he might drinke to dead Pantagruel.

(III.vi.1-4)

A search of Early English Books Online for the phrase "who knows not" confirms that "who knowes not Gullion?" imitates a phrasing characteristic of Spenser. This sort of parenthetical rhetorical question appears only twice before Hall's use of it, and both are from Spenser. In "August" of Spenser's Shepheardes Calender (1579), Cuddie asks Willye and Perigot if they would like to hear "a doolefull verse / Of Rosalend (who knowes not Rosalend?) / That Colin made" (lines 140-42). Spenser follows the same pattern in Book 6 of The Faerie Queene (1596): "That iolly shepheard, which there piped, was / Poore Colin Clout (who knowes not Colin Clout?)" (6.10.16.3-4). The only other appearance of this structure before 1600 occurs in another one of the satires banned in 1599, Thomas Middleton's Micro-Cynicon: Sixe Snarling Satyres (1599), where "Who knowes not Zodon" presumably imitates this Spenserian verbal structure, just as Hall does.

Following his request to drink to Pantagruel, the gluttonously thirsty Gullion proceeds to drink the river Acheron, all of it, such that Charon can no longer transport the ghosts.

Yet stand they still, as tho they lay at rode,
Till Gullion his bladder would vnlode.
They stand, and wait, and pray for that good houre:
Which when it came, they sailed to the shore.

(Hall, Virgidemiae, III.vi.19-22)

Here again we see the pattern of a clear reference to Spenser followed by a disgusting and indecorous image. Hall's image of a river created by a drunkard's piss certainly aims at a different reaction from the reader than Spenser's considerably more polite allegory of bodily waste in his creation of Port Esquiline in the House of Alma. He uses allusion to conjoin Rabelais and Spenser, linguistically calling to mind the pastoral world of Colin Clout while creating the Rabelaisian image of Gullion's excess. The two 
examples I discussed earlier occur at the beginning of the collection of Toothless Satyres, the second and third satires of the first book. The satire on Gullion appears as the penultimate satire of the third book, and thus near the end of the installment that was published in 1597.

So ... why? And so what? Why does Hall allude to "renowmed Spenser" at his most disgusting moments? I believe that he does so because inviting the reader to contrast Hall's disgusting images with Spenser's famous decorum creates the implicit argument that Hall's apparent indecorousness stems not from ignorance but from moral outrage. Wayne Rebhorn, in his analysis of how three Renaissance rhetoricians treated the concept of decorum, notes that such English writers as Thomas Wilson and George Puttenham identify indecorousness as a marker of low birth and social status and thus advise their rhetor against, in Wilson's words, "scurrilitie, or ale-house jesting" and "Ruffine maners" (qtd. in Rebhorn, "Outlandish fears"). ${ }^{11}$ Spenser endorses this view in Teares of the Muses, when Thalia complains of the "scoffing Scurrilitie" and "rymes of shameles ribaudrie" that go against "due Decorum" in comic poetry (lines 211, 213, 214).

If Hall does not put forth a rationale for using scurrilous language, he risks being interpreted as merely one of the barbarous, ignorant rhymers that the Muse Thalia weeps about. Part of his argument that he is not indecorous, but instead adheres to the decorum of satire, appears in critical comments throughout the satires, as R.B. Gill notes ("Purchase of glory"). ${ }^{12}$ Equally important, though, are the ways that he distinguishes himself from the ignorant by demonstrating his knowledge of and ability to adapt creatively the works of both classical and English authors. ${ }^{13}$ Certainly Hall's creative allusions to Spenserian motifs and quotations function in this manner. Through these allusions, Hall shows that he

11 Rebhorn unpacks the significance of the word "scurrilitie" with reference to the Latin word scurra: "By speaking of 'scurrilitie,' Wilson both invokes the lower class clown of Rome, thus connecting his treatise to the classical past it imitates, and brings the scurra up to date by identifying him with the lower class habitues of the Renaissance tavern, that is, with thieves, coney-catchers, impoverished second sons, and declasse knights, with characters such as Shakespeare's Bardolph, Pistol, Poins, and Falstaff" (paragraph 13).

12 Alvin Kernan, considering Spenser's Mother Hubberds Tale as an example of what Elizabethan readers would recognize as a decorous "base style" for satire, compares John Marston's language to the standard of Mother Hubberds Tale and concludes that "Marston's diction lies for the most part entirely outside the area recognized as suitable for poetry of any kind." One could argue the extent to which Marston's language is more disgusting than Hall's, but Hall's language is certainly closer to Marston's than to Spenser's (Kernan, Cankered Muse, 100n8).

13 Regarding Hall's demonstrations of learnedness, see Davenport, "Interfused sources"; and Arnold Stein, "Joseph Hall's imitation." 
knows and understands Spenser's practice of decorum and consciously chooses to follow a different idea of decorum, one appropriate to a satiric response to a corrupt world. The first three books of Virgidemiarum focus primarily on cultural critique and the final three books rather more on political critique, but the tone of moral outrage remains fairly consistent throughout the collection. ${ }^{14}$ Hall's engagement with Spenser seems to imply that for one who couches his religious and political commentary in allegories of "Eluish knights" and "striuing shepheards," the "stately Stanzaes" of Spenser are appropriate and decorous ("Defiance," lines 49, $85,55)$. For hmself, though, who wishes to score more direct satirical hits, only "refuse rimes" will do ("Defiance," line 113).

Although the meaning of "Spenser" as a bundle of ideas about the man Spenser was relatively stable, his meaning to and influence on individual authors varied by person, based on numerous factors including political and religious commitments, anxieties about censorship, ideas about genre, and so forth. The ideological diversity of the authors considered in this book suggests something of the importance of Spenser's position in the literary system of late Elizabethan England: even authors who presumably found little to appreciate in Spenser's ideas about religion or politics-such as the Catholic Tailboys Dymoke or Thomas Nashe, whose Choise of Valentines suggests a critical stance toward the political faction with which Spenser was associated-found it worthwhile for their projects to engage with Spenserian works to create satirical meanings.

Poets more closely aligned with Spenser in terms of their loyalties respond to Spenser not only as a figure with disproportionate visibility and status within the literary system, but also as an ally. Under the capricious and sometimes harsh censorship of the Elizabethan government, the ability to circuitously signal one's own alignment with the religious and political beliefs associated with Spenser by alluding to him, as I argue that Thomas Middleton does, becomes an additional way to create and convey meaning in a deniable way. Later, as authors try to find the new lines not to cross under the Jacobean government, Spenser retains his value as a toweringly significant author understood to stand for a particular set of meanings and values. Throughout the period, his status as a canonized and central author helps us to understand the use made of him by other authors writing in the noncanonized and peripheral area of satire.

14 See McCabe (Joseph Hall, 56-66), for fuller discussion of Hall's political and religious sympathies that appear in the Virgidemiarum, including opposition to enclosure and sympathy for the poor. 